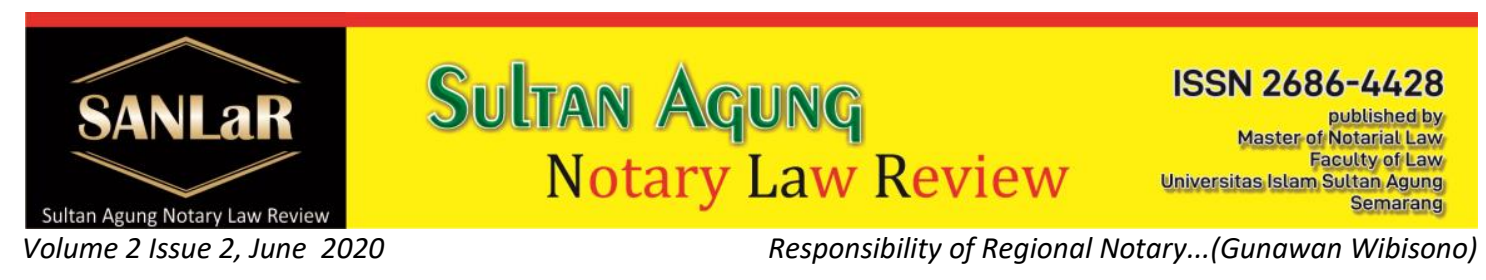

\title{
Responsibility of Regional Notary Supervisory Council for Protocol Transfer of Died Notary
}

\section{Gunawan Wibisono*)}

*) Students of Master of Notary Law, Universitas Islam Sultan Agung (UNISSULA) Semarang, E-mail: gunawanwibisno@gmail.com

\begin{abstract}
The purpose of this study was to analyze: 1) The role of the Regional Supervisory Council on the responsibility of the Notary Public Protocol who has passed away in Jepara Regency. 2). The liability of the heirs to the protocol of the deceased notary public. The approach method to discuss this research is juridical empirical. This type of research is classified as a descriptive analytical research. Data collection was obtained from primary data and secondary data, by means of interviews and literature study. The data analysis technique is qualitative data analysis. The research results are: 1). The role of the Regional Supervisory Council for the responsibility of the Notary Public Protocol who has passed away in Jepara Regency, namely the MPD of the Jepara Regency working area as the supervisory council has played an active role in providing guidance and supervision to Notaries. MPD's firmness, especially regarding the Notary protocol that must be applied, so that when a Notary dies, such as the case of notary Muhammad Chaidzar, SH. M.Kn, and the protocol has been submitted to another notary appointed by the MPD. Legal aspects related to the accountability of the heirs of a capable Notary by immediately submitting the Notary protocol to another Notary who is appointed by MPD as the Notary holding the protocol. 2). The obligation of the heirs to the protocol of the deceased Notary is that the State archives in the form of documents that have been made by the notary must be kept, by submitting the Notary protocol through the MPD because of its authority. The responsibility of a notary public for a notary protocol that has not been submitted to another notary in this case can be categorized as an act of legal competence. Actions proficient in law here are defined as the implementation of the heir's responsibility in carrying out or submitting the protocol of the deceased.
\end{abstract}

Keywords: Responsibility; Supervisory; Protocol; Died Notary.

\section{Introduction}

Developmentsocial, resulting in the development of legal relations in society, so the role of the Notary is very complex and often very different from the prevailing regulations. Thus it is difficult to completely define the tasks andprofession Notary Public. ${ }^{1}$ Notary as a public official is one of the state organs equipped with legal

\footnotetext{
${ }^{1}$ Adjie, Habib. (2003). Tebaran Pemikiran Dalam Dunia Notaris Dan PPAT "Penegakan Etika Profesi Notaris Dari Prespektif Pendekatan Sistem. Surabaya: Indonesian Notary Research Institute and PPAT.p. 27
} 
authority to provide public services to the public, especially in making authentic deeds as perfect evidence with respect to legal actions in the civil sector. ${ }^{2}$

Notary is a public official who has the authority to make authentic deeds and other powers as referred to in the Law on Notary Position.In addition, a notary is a position of trust that is trusted by the public to put in writing what is the will of the parties into a deed that has been determined by law. So that notaries in exercising their authority must act honestly, thoroughly, independently, not taking sides and guarding the interests of the parties involved in legal actions. ${ }^{3}$ In this regard, in 2004 Act No. 30 of 2004 concerning the Position of Notary (as a substitute for Staatbald 1860 number 30) was promulgated which was later amended by Law of the Republic of Indonesia Number 2 of 2014 Amendment to Act No. 30 of 2004 concerning the Position of Notary Public . Hereinafter, in this paper it is abbreviated as the Law on the Position of Notary Public.

In Article 1 number 13 of Act No. 2 of 2014 concerning the Position of Notary Public, it states that the notary protocol is a collection of documents which are state archives that must be kept and maintained by a notary public. Whereas in Article 62 of the Law on notary position Number 30 of 2004 concerning Notary Position, it is stated that the submission of the notary protocol is carried out in the event that the notary dies, has expired his term of office, asks for himself, is spiritually and or physically unable to carry out his duties as a notary publicly. Continuously for more than 3 (three) years, Appointed as state official, Changing position, temporarily suspended, or dishonorably discharged

Whereas regarding the submission of notary protocols regulated in Article 63 of Act No. 2 of 2014 concerning Notary Position, namely:

a. The submission as referred to in article 62 shall be carried out at the latest 30 (thirty) days by drawing up the Protocol as in the minute of submission of the notary protocol signed by the submitting and receiving the Notary Protocol.

b. In the case as referred to in Article 62 letter a, the Notary's heirs shall submit the Notary Protocol to another Notary who is appointed by the Regional Supervisory Council.

c. In the case as referred to in Article 62, the Notary Protocol shall be submitted by the Notary to another Notary appointed by the Regional Supervisory Committee if the suspension is more than 3 (three) months.

d. In the case as referred to in Article 62 letter b, letter $c$, letter $d$, letter $f$, or letter $h$, the Notary's Protocol shall be submitted by the Notary to another Notary appointed by the Minister upon the recommendation of the MPD.

\footnotetext{
${ }^{2}$ N.G. Yudara. (2006). Notaris dan Permasalahannya (Pokok-Pokok Pemikiran Di Seputar Kedudukan Dan Fungsi Notaris Serta Akta Notaris Menurut Sistem Hukum Indonesia), Paper presented in the context of THIS Congress in Jakarta: Renvoi Magazine No. 10.34.III. p. 72

${ }^{3}$ Salim HS. (2006). Hukum Kontrak - Teori dan Teknik Menyusun Kontrak. Jakarta: Sinar Grafika.p. 43
} 
e. Notary Protocol from another Notary who at the time of delivery is 25 (twenty five) years old or more submitted by the Notary Public who receives the Notary Protocol to the Regional Supervisory Council.

f. (2) In the event that the Notary Protocol is not submitted within the 30 (thirty) day period as referred to in paragraph (1), the Regional Supervisory Council has the authority to adopt the Notary Protocol.

Notaries are directly responsible for the Notary protocol. However, in reality what is happening in the community at this time is that not all of these Notaries can understand the notary protocol submission procedure and are willing to carry out their obligation to submit the Notary protocol to the Notary who has been appointed by the Regional Supervisory Council to accept the notary protocol transfer. This has caused confusion among the people who need the notary protocol, which should be kept and maintained by a Notary appointed by the Regional Supervisory Council. Indirectly, it can have fatal consequences and even cause very large material losses to the public who will or still need the deed contained in the Notary Protocol for the purposes of legal certainty.

\section{Research Methods}

The approach method used in discussing this research problem is the empirical juridical approach method. Juridical empirical is a legal research method that seeks to see the law in a real sense or it can be said to see, research, how the law works in society. ${ }^{4}$ This type of research is classified as a descriptive analytical study. The collection of data obtained from primary data and secondary data, using interview methods and literature study. The data analysis technique used qualitative data analysis.

\section{Results and Discussion}

3.1. The role of the Regional Supervisory Council (MPD) on the responsibility for the protocol of notaries who have passed away in Jepara Regency

The law functions as a means of community renewal and protection of society so that laws need to be developed in a planned manner so that law as a means of community renewal can run harmoniously, in balance, in harmony and in turn the life of law reflects justice, social benefits and legal certainty. ${ }^{5}$

Notary is a public official who is the sole authority to make an authentic deed regarding all actions, agreements and decisions required by a general rule or by an interested party who wants to be stated in an authentic deed to guarantee the certainty of the date, keep the deed and provide grosse, copy and excerpt. , all of them

\footnotetext{
${ }^{4}$ Narbuko, Cholid. (2002). Metodologi Penelitian. Jakarta: PT. Bumi Aksara. p.14

${ }^{5}$ Tedjosaputra, Liliana. (1994). Etika Profesi Notaris Dalam Penegakan Hukum Pidana. Yogyakarta: Biagraf Pubslishing. p. 4
} 
as long as the making of the deed by a general regulation is not assigned or excluded to other officials or persons. ${ }^{6}$

Officials who have the authority to appoint and dismiss Notaries are stated in Article 2 of Act No. 30 of 2004 concerning Notary Positions, namely the Minister. ${ }^{7}$ Minister is the minister who holds government affairs in the field of law. If the authority is required from the Ministry of Law and Human Rights, it appears that the Ministry of Human Rights, not only has the authority to appoint a Notary, but also makes arrangements and guidance on the field of Notary requirements. Efforts to develop and supervise are carried out by forming a Notary Supervisory Council. ${ }^{8}$

Based on facts in the field, after the death of one of the Notaries in the Jepara Regency Work area, Muhammad Chaidar, SH., M.Kn, who had passed away and was the recipient protocol of notary namely Mr.Ridhol Wasiq ,. SH. This is due to several things, such as statements from the MPD and BPN as well as from officials of the Ministry of Human Rights, that the Notary's protocol must be made by notary officials with the closest family relationship, while the notary concerned refuses to accept protocals on the grounds of maintaining ethics. Meanwhile, another notary was appointed by the Ministry of Law and Human Rights. Suryani SH., M.Kn. refused on the grounds that he was worried when there was a dispute that he had to be responsible, as well as Notary Neneng, SH., M.Kn, he refused on the grounds that a new notary was and was afraid that a dispute would occur later on from the existing files. ${ }^{9}$

Due to the above incident, the problem of the late Sugi Endro Amiarso's notary protocol has yet to be resolved and is still in the hands of the heirs. Whereas Expert sis. lin, $\mathrm{SH}$ (wife of the deceased = researcher) has submitted the notary protocol to MPD according to the predetermined time. Based on the provisions of Article 63 paragraph [2] of Act No. 30 of 2004 concerning the Position of Notary Public ("UUJN"). If the notary passes away, the Notary Protocol will be submitted by his heirs to another notary appointed by the Regional Supervisory Council ("MPD"). According to the Chairperson of the MPD of Jepara Regency, Fatchur Rohman SH, MPD has carried out the duties and functions of the MPD as mandated in the UUJN, namely supervising the performance of Notaries in their working area, including deliberating every notary who has retired for various reasons, both retirement and death. As for the problem of notaries who have passed away and the protocol is not simply left to the notary who received the protocol, it must be seen from various considerations, such as social and psychological considerations. For the case of the death of Muhammad Chaidar, SH., M.Kn. who was handed over to the protocol and there were several obstacles from the MPD and it was MPD's job to guard and find the best solution for everyone.

The notary protocol is a very important part of the State documentary, so heirs must be careful and painstaking in making minutes, as explained in the UUJN, that what is meant by a notary protocol here is a collection of documents which are state archives that must be kept and preserved by a Notary, as regulated in article 1 number 13

\footnotetext{
${ }^{6}$ Tobing, G.H.S Lumban. (1992). Peraturan Jabatan Notaris. Jakarta: Erlangga. p.31

${ }^{7}$ Salim H. S. (2010). Perkembangan Teori Dalam IImu Hukum. Jakarta: Rajawali Pers. p.38

8 Ibid. p. 39

${ }^{9}$ Observations and Facts in the Field and interviews with the chairman of the Jepara of MPD
} 
UUJN). The Notary Protocol, according to the explanation of article 62 UUJN, consists of: ${ }^{10}$
a. Minuta Deed;
b. Deed register book or repertorium;
c. An underhand deed list book which is signed by a notary public or an underhand registered deed;
d. Book lists the names of the tapes or clamps; protest list book;
e. Book of testament list; and
f. Other register books that must be kept by the Notary based on the provisions of the legislation.

The UUJN also stipulates that if the Notary dies while on leave, the duties of the Notary Public shall be carried out by the Substitute Notary as a Notary Public notary for a maximum of 30 days from the date of the Notary's death (Article 35 paragraph [3]). The Temporary Officer of Notary Public is obliged to submit Notary Protocol from Notary who passed away to MPD within 60 days from the date of the Notary's death (Article 35 paragraph [4]). Storage and maintenance of the Notary Protocol continues even though the Notary concerned has retired or has passed away. The Notary Protocol is submitted to another Notary as the Notary Protocol Holder.

The transfer of the Notary protocol from a Notary's heir who has passed away to another Notary who is appointed by the Regional Supervisory Council as the holder of the Notary protocol has not been specifically regulated. In practice, there are still many Notary heirs who have not submitted the Notary protocol to another Notary as the holder of the Notary protocol. The regulations regarding the Minutes of Deed and Notary Protocol contained in UUJN and UUJNP are only limited to making, storing and submitting Notary protocols as well as taking minuta of deeds and summons of Notaries as contained in Article 58 to Article 66. does not immediately submit the Notary protocol to the Notary holding the protocol.

Lack of socialization to families, notary heirs, employees and the public in general regarding the Notary protocol and authentic deeds as evidence causes problems that will result in losses to the community, because heirs of the Notary's family who died still keep the Notary's protocol and have not. submit the Notary protocol to another Notary as the holder of the Notary protocol. ${ }^{11}$

One of the reasons for the termination of one's position as a Notary is because the Notary concerned has passed away. With the death of a Notary, all his responsibilities end and the relevant Notary Public Protocols must be immediately submitted to the Regional Supervisory Council (hereinafter referred to as MPD) through their heirs to be kept by the Notary who holds the protocol who has been appointed. So it is clear that there is a function and supervision of the MPD on file storage or documentary that is

\footnotetext{
${ }^{10}$ Interview with Fathcur Rohman, SH, as MPD Jepara Regency, March 20, 2020

${ }^{11} \mathrm{lbid}$.
} 
made by a notary, whether the notary is still active until the notary is full of duty or even the notary dies.

This information is confirmed in Article 63 paragraph (2) of Act No. 30 of 2004 jo. Act No. 2 of 2014, namely: "In the event of what happens as referred to in Article 62 letter a, the Notary's heirs shall submit the Notary Protocol to another Notary appointed by the Regional Supervisory Council."

Notaries are directly responsible for the Notary protocol. However, in reality what is happening in society today is that not all of these Notaries can understand the procedure for submitting Notary protocols and are willing to carry out their obligations to submit Notary protocols to Notaries who have been appointed by the Regional Supervisory Council. It is the same when a notary passes away. Sometimes the heirs of the Notary do not understand the procedures or procedures for switching the Notary protocol. This is due to the lack of socialization regarding the Notary protocol, both from Notaries to their families, Notaries to employees, from MPD and Notary organizations to Notaries as well as from MPD and Notary organizations to the wider community. The lack of socialization regarding this Notary protocol has caused confusion in the community who need a protocol that should be kept and submitted to a Notary who is appointed by the Regional Supervisory Council. Indirectly, it can have fatal consequences and can even cause very large material losses to the public who will or still need the deed contained in the Notary protocol who is retired or has passed away for the purposes of legal certainty.

In article 62 of the UUJN regarding the position of a Notary, it is stated that the submission of the Notary protocol in the event of a Notary who dies. In relation to the protocols of Notary who pass away, UUJN provides provisions for submitting these protocols to MPD through their heirs for a maximum of 30 (thirty days) after the Notary concerned dies. Furthermore, the protocol is submitted to another notary as the protocol holder. (Article 63 paragraph (1) Act No. 30 of 2004 in conjunction with Act No. 2 of 2014).

In principle, every time a Notary dies, it is based on Article 35 paragraph (2) of Act No. 2 of 2014 concerning the Position of Notary, then: The family is obliged to notify MPD Notary at the latest 7 (seven) working days. The provisions in Article 62 letter a UUJN explain that in the event that a Notary passes away, the Notary's protocol will be submitted to another Notary. The heirs will submit the protocol to a Notary Public who has passed away to another Notary appointed by the MPD as stated in Article 63 paragraph (2) UUJN.

In addition to the foregoing, the authority of the MPD is also regulated in the UUJN, we see in the UUJN, the Supervisory Council in the UUJN and the Amendment UUJN are regulated in the following articles Article 68, the Supervisory Council as referred to in Article 67 paragraph (2) consists of the MPD, MPW and MPP. The powers of the Regional Supervisory Council based on the provisions of Article 70 of the UUJN are: 
a. Holding hearings to examine any suspected violations of the Notary Code of Ethics or violations of the implementation of the Notary's Position;

b. Checking the Notary protocol periodically 1 (one) time in 1 (one) year or every time deemed necessary;

c. Give leave permission for a period of up to 6 (six) months;

d. To determine a substitute notary by taking into account the recommendation of the notary concerned;

e. Determine the storage location for the Notary Protocol which at the time of handover of the Notary Protocol has been 25 (twenty five) years old or more;

f. Appoint a Notary who will act as the temporary holder of the Notary Protocol who is appointed as a State Official as referred to in Article 11 paragraph (4);

g. Receive reports from the public regarding suspected violations of the Notary Code of Ethics or violations of the provisions of this Law; and

h. Prepare and submit reports as referred to in letter $a$, letter b, letter $c$, letter $d$, letter $\mathrm{e}$, letter $\mathrm{f}$ and letter $\mathrm{g}$ to the Regional Supervisory Council.

Article 71 UUJN, MPD is obliged to:

a. Record in the register included in the Notary protocol by stating the date, number of deeds as well as the number of letters under hand which were legalized and recorded since the date of the last examination;

b. Make an examination report and submit it to the local MPW, with a copy to the relevant Notary, Notary organization, and MPP;

c. Keep secret the contents of the deed and the results of the examination;

d. Receive an approved copy of the list of deeds and other lists from the Notary and keep it confidential;

e. Checking public reports against the Notary and submitting the results of the examination to MPW within 30 days, with a copy to the reporting party, the Notary concerned, MPP and Notary organizations;

f. Submit an appeal against the decision to refuse leave.

As we know, the Notary Protocol as a state archive is a very important document so that it cannot be lost or destroyed. Meanwhile, if this important state archive is stored in an ordinary place such as a home or office, the risk of loss or destruction of this archive is very high, therefore the law mandates that if a Notary dies, the heirs of the Notary who pass away will immediately notify MPD and then MPD appoints another Notary as the holder of the protocol of the Notary who has passed away. Regarding the obligation to submit the Notary protocol, not all heirs understand and immediately implement it, so that the Law provides a solution by giving the MPD the authority to adopt the Notary protocol as confirmed in Article 63 paragraph (6) of the UUJNP. Based on the provisions of Article 63 paragraph (6) UUJNP which confirms that:

"In the event that the Notary Protocol is not submitted within 30 (thirty) days as referred to in paragraph (1), the Regional Supervisory Council has the authority to adopt the Notary Protocol", if there is a Notary Public who has passed away and the 
Notary Protocols have not been submitted by experts. Notary's inheritance to MPD or even if there is no Notary holder of the protocol, MPD should immediately act proactively and immediately take steps to resolve the neglected Notary protocol. The law has given full authority to the MPD to resolve issues of the Notary protocol that have not been resolved. This is where MPD's firmness is needed regarding the process of submitting and storing the deceased Notary's protocols to comply with the regulations. $^{12}$

Based on the description above, UUJN has given the authority to the Notary Supervisory Council, the public and Notary organizations, to supervise through the mechanisms and procedures as described above, of the Notary's and Notary's deeds in carrying out their positions as Notary Protocol holders.

\subsection{Obligations of the heir to the Notary Protocol who died}

Notarial institutions in Indonesia originate from the Netherlands and have been known since the Dutch colonized Indonesia. Initially, this notarial institution was primarily intended for the Dutch and other European groups as well as the Bumi Putera group who, due to law or because of some provisions, were declared subject to the law applicable to European groups in the field of civil law or subjected themselves to the Burgelijk Wetboek (BW) or generally referred to as the Civil Code. ${ }^{13}$

In principle, every time there is a Notary who dies, based on Article 35 of Act No. 30 of 2004 concerning the Position of Notary Public ("Law on the Position of Notary"), then: his family is obliged to notify MPD Notary at the latest 7 (seven) working days. If the Notary dies while taking leave, the duties of the Notary Public shall be carried out by the Notary as a Substitute Notary Public notary for no later than 30 (thirty) days from the date of the Notary's death. The Temporary Notary Officer submits the Notary protocol from the Notary who dies to MPD no later than 60 (sixty) days from the date of the Notary's death. ${ }^{14}$

In the event that the Notary Public dies, the Notary Public Protocol will be submitted to another Notary who will replace him (Article 62 letter a Law on Notary Position). The submission of the protocol in the event that the Notary dies, is carried out by the Notary's heirs to another Notary who is appointed by the MPD (Article 63 paragraph (2) of the Law on Notary Position). Through this article, we can see that another Notary who will accept the Notary's protocol who has passed away is a Notary who is appointed by the MPD. The submission of the protocol is carried out in no later than 30 (thirty) days by making an official report on the submission of the Notary protocol signed by the person submitting and receiving the Notary protocol (Article 63 paragraph (1) of the Law on Notary Position).

\footnotetext{
${ }^{12}$ Wahyuni, \& Ma'ruf, Umar. (2020). The function of the Notary / PPAT In filing process Acquisition of Land Rights To Interests Investment in Regional Autonomy Era Based on Act No. 25 of 2007 concerning Foreign Investment. JURNAL AKTA: Vol.7, No. 2, 189-194. Retrieved from http://jurnal.unissula.ac.id/index.php/akta/article/view/7965

${ }^{13}$ Notodisoerjo, R. Soegondo. (1993). Hukum Notariat di Indonesia, Suatu Penjelasan, Second Edition. Jakarta: Raja Grafindo Persada. p. 1

${ }^{14}$ Tobing, G.H.S. Lumban. (1983). Peraturan Jabatan Notaris. Jakarta: Erlangga. p. 72
} 
Notary Protocol, which is an archive of State documents, serves as strong evidence that must be kept and maintained by the Notary Public. Evidence in procedural law has a juridical meaning, meaning it only applies to parties who are involved or who have obtained rights from them and the purpose of this evidence is to provide certainty to judges regarding the existence of certain events. ${ }^{15}$

The Notary Protocol regulated in this law is a very important state archive, which must be maintained and safeguarded by a Notary because it is a valid and strong evidence if there is a problem between the parties in a deed. If the Notary concerned has no longer served as a Notary or for some reason the Notary Protocol has been transferred or transferred to another Notary as the Notary Protocol Holder and the parties who are or are related in a deed wish to find documents whose act is drawn up in the past. then these documents will be easily found with the Notary Protocol from the Notary which has been submitted or transferred to another Notary who is assigned as the Notary Protocol Holder.

From the description above, it can be seen that the notary is still responsible for the deeds he makes after the submission of the protocol to the protocol depositor, especially notaries who do not want to submit the notary protocol to the notary receiving the protocol can be categorized as an illegal act. Notary protocol is a collection of documents which are state archives which must be kept and maintained by a notary public. The notary protocol consists of: Minuta deed, List of deeds or Repertorium, Book of list of deeds under the hands of which the signing is done before a Notary or deed under the registered hand, Book of names of tappers or klapper, Book of protest list, book of wills, other books kept by the Notary. If the notary has passed away, the husband/wife heirs, blood relatives in a straight line of lineage of two seminars are obliged to notify the Regional Supervisory Council, the notification is no later than 7 (seven) working days, the obligation of the heir of the notary dies apart from notifying the Regional Supervisory Council, then the heirs are obliged to submit the notary protocol., Protocol The notary must be submitted no later than 30 (thirty) days by making an official report on the submission of the notary protocol signed by the submitting and receiving the notary protocol. If the Notary Protocol is not submitted by the heirs, the Regional Supervisory Council will take legal action, namely to provide opportunities for the heirs, give written warnings and propose a notary holding the protocol and convey it to the Minister.

\section{Closing}

The obligation of the heirs to the protocol of the deceased Notary is that the State archives in the form of documents that have been made by the notary must be kept, by submitting the Notary's protocol through the MPD because of its authority. The responsibility of the notary public for the notary protocol that has not been submitted to another notary, in this case can be categorized as an act of legal competence. Actions proficient in law here are defined as the implementation of the heir's responsibility in carrying out or submitting the protocol of the deceased.

\footnotetext{
${ }^{15}$ Mertokusumo, Sudikno. (1998). Hukum Acara Perdata Indonesia. Yogyakarta: Liberty. p.26- 27
} 


\section{References}

\section{Journal:}

Wahyuni, \& Ma'ruf, Umar. (2020). The function of the Notary/PPAT In filing process Acquisition of Land Rights To Interests Investment in Regional Autonomy Era Based on Act No. 25 of 2007 concerning Foreign Investment. JURNAL AKTA: Vol.7, No. 2, 189194. Retrieved from http://jurnal.unissula.ac.id/index.php/akta/article/view/7965

\section{Books:}

[1] Adjie, Habib. (2003). Tebaran Pemikiran Dalam Dunia Notaris Dan PPAT "Penegakan Etika Profesi Notaris Dari Prespektif Pendekatan Sistem. Surabaya: Indonesian Notary Research Institute and PPAT

[2] Mertokusumo, Sudikno. (1998). Hukum Acara Perdata Indonesia. Yogyakarta: Liberty

[3] N.G. Yudara. (2006). Notaris dan Permasalahannya (Pokok-Pokok Pemikiran Di Seputar Kedudukan Dan Fungsi Notaris Serta Akta Notaris Menurut Sistem Hukum Indonesia), Paper presented in the context of THIS Congress in Jakarta: Renvoi Magazine No. 10.34.III.

[4] Narbuko, Cholid. (2002). Metodologi Penelitian. Jakarta: PT. Bumi Aksara

[5] Notodisoerjo, R. Soegondo. (1993). Hukum Notariat di Indonesia, Suatu Penjelasan, Second Edition. Jakarta: Raja Grafindo Persada

[6] Salim H. S. (2010). Perkembangan Teori Dalam Ilmu Hukum. Jakarta: Rajawali Pers.

[7] Salim HS. (2006). Hukum Kontrak - Teori dan Teknik Menyusun Kontrak. Jakarta: Sinar Grafika

[8] Tedjosaputra, Liliana. (1994). Etika Profesi Notaris Dalam Penegakan Hukum Pidana. Yogyakarta: Biagraf Pubslishing

[9] Tobing, G.H.S Lumban. (1992). Peraturan Jabatan Notaris. Jakarta: Erlangga

Interview:

Interview with Fathcur Rohman, SH, as MPD Jepara Regency, March 20, 2020 